\title{
Physiological and morphological traits of tulip (Tulipa sp.) as affected by different concentrations of ethanol and methanol
}

\author{
Sajedeh Ramazannejad ${ }^{1}$ (D), Shahram Sedaghathoor ${ }^{1 *}$ (D) \\ ${ }^{1}$ Rasht Branch, Islamic Azad University, Rasht, Iran.
}

\begin{abstract}
Tulip (Tulipa sp.) is of the highest economic importance and cultivated area among all bulbous ornamental species. The spray of alcohol is regarded as a proper strategy to improve plant yields in sustainable agriculture systems. This study aimed to investigate the effect of different rates of ethanol and methanol on the traits of the tulip in a factorial experiment based on a Randomized Complete Block Design with two factors including ethanol at four levels $(0,10,20$, and $30 \mathrm{vol} \%)$ and methanol at four levels $(0$, 10,20 , and $30 \mathrm{vol} \%$ ). The estimated traits included anthocyanin, carotenoid, chlorophyll $a$ and $b$, total chlorophyll, stem and leaf Brix index, leaf length and width, leaf area, total and bulb fresh and dry weight, leaf number, and flowering stalk length. Analysis of variance showed that the simple and interactive effects of different treatments were statistically significant on most estimated traits. The highest anthocyanin content $\left(3.92 \mathrm{mg} 100 \mathrm{~g}^{-1} \mathrm{DM}\right)$, leaf length $(25.83 \mathrm{~cm})$, leaf area $\left(258.6 \mathrm{~cm}^{2}\right)$, and bulb fresh weight

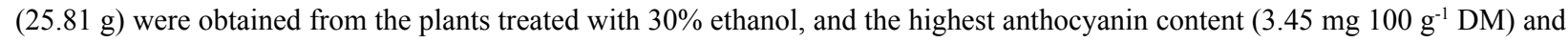
leaf Brix index (10.15\%) were related to $30 \%$ methanol. It can be concluded from the results that methanol and ethanol can be used as plant growth regulators.
\end{abstract}

Keywords: anthocyanin, carotenoid, ethyl alcohol, methyl alcohol.

\section{Resumo}

Influência de diferentes concentrações de etanol e metanol nas características fisiológicas e morfológicas de Tulipa (Tulipa sp.)

A tulipa (Tulipa sp.) é uma espécie ornamental bulbosa com alta relevância econômica e grande área cultivada. A aspersão de álcool é estimada como uma estratégia válida para aumentar a produtividade de plantas em sistemas sustentáveis de agricultura. Este estudo objetivou investigar o efeito da aplicação de diferentes proporções de etanol e methanol nas características de tulipas utilizando um esquema factorial baseado em um design de blocos completamente aleatório, com dois fatores incluindo etanol em quatro níveis $(0,10,20$ e 30 vol\%) e metanol em quatro níveis $(0,10,20$ e 30 vol\%). As características avaliadas incluíram antocianinas, carotenoids, clorofila $a$ e $b$, clorofila total, índice Brix das folhas e hastes, comprimento e largura das folhas, área foliar, peso fresco e seco dos bulbos, número de folhas e comprimento da haste floral. A análise de variância mostrou que efeitos significativos simples e de interação entre os diferentes tratamentos na maioria das características avaliadas. $\mathrm{O}$ maior valor de antocianina (3.92 mg $\left.100 \mathrm{~g}^{-1} \mathrm{DM}\right)$, comprimento foliar $(25.83 \mathrm{~cm})$, área foliar $\left(258.6 \mathrm{~cm}^{2}\right)$, e peso fresco de bulbo $(25.81 \mathrm{~g})$ foram obtidos em plantas tratadas com 30\% de etanol, e o maior valor de antocianina (3.45 mg $\left.100 \mathrm{~g}^{-1} \mathrm{DM}\right)$ e índice Brix foliar (10.15\%) foi relacionado com a aplicação de $30 \%$ de metanol. Conclui-se a partir dos resultados que methanol e etanol podem ser usados como reguladores do crescimento de plantas.

Palavras-chave: antocianina, carotenoide, álcool etílico, álcool metílico

\section{Introduction}

Given the fact that the overuse of chemical inputs and plant growth regulators in recent decades for higher crop production has damaged the environment and human health, the global community has been interested in the use of technologies for environmental conservation and sustainability. In this respect, the spray of alcohol, especially methanol and ethanol, is regarded as a strategy to improve plant yields (Valizadeh-Kamran et al., 2019). Benson and Nonomura (1992) reported that methanol can increase plant growth by reducing photorespiration. Tavassoli and Galavi (2011) indicated that the foliar spray of methanol improved the growth and yield of $\mathrm{C}_{3}$ plants. They believe that methanol may act as a carbon source for the plant and a photorespiration inhibitor. Higher plants

*Corresponding author: sedaghathoor@yahoo.com 
produce methanol as a result of pectin demethylation. This compound is produced especially during the primary phases of leaf growth. Plant tissue can also make use of methanol. Although there is no methanol oxidase in higher plants, they can convert methanol to $\mathrm{CO}_{2}$. The assimilation of methanol by plants happens before its oxidation (Ramadan and Omran, 2005). The useful effects of the methanol spraying on growth and yield of different plants have been reported by (Ramadan and Omran, 2005) in grapevine and (Zheng et al., 2008) in wheat.

Khosravi et al. (2016b) observed the highest plant height, leaf dry weight, capitulum dry weight, and root dry weight of Echinacea purpurea in plants sprayed with $40 \%$ methanol, whereas the highest leaf area and chlorophyll content were obtained from the foliar application of $30 \%$ methanol. They concluded that the foliar application of methanol and ethanol would improve the biomass and yield of $E$. purpurea L. because they would act as a source of carbon and bio-stimulator. Sajedi Moghadam et al. (2012) found that the treatment with alcohol improved Thymus vulgaris growth and development, yield, and the formation of vegetative organs. The highest yield of thyme was obtained from $30 \%$ methanol and $20 \%$ ethanol. They can, also, increase the accumulation of carbohydrates and $\mathrm{CO}_{2}$ concentration (Zbiec et al., 2003). Larzghadiri et al. (2013) obtained the highest leaf length and leaf chlorophyll of Plantago psyllium under 30\% methanol application and also, the highest leaf fresh and dry weight and leaf width were obtained from $20 \%$ methanol treatment. However, the lowest ones were observed in the control samples. Methanol metabolism in plants is similar to $\mathrm{CO}_{2}$ metabolism. The use of methanol as a carbon source for crops has been progressively advised because leaves can easily take up methanol and use it as a carbon source besides the atmospheric $\mathrm{CO}_{2}$ (Moradi and Esfahani, 2016; Tavassoli and Galavi, 2011). The root application of methanol caused phytotoxic damage in Arabidopsis, tobacco, and tomato plants. But, foliar application improves fresh and dry weight in Arabidopsis and tobacco plants. The increase in the weight of Arabidopsis is not related to the increase in the sugars (Ramírez et al., 2006).

The central and western provinces of Iran have tremendous potential to produce bulbous plants including tulip because of their specific geographical conditions and ideal climate. The present study aimed at examining the effect of different rates of ethanol and methanol on some traits of tulip and comparing ethanol and methanol in terms of their impact on the yield of this flower. We hypothesized that alcohol can improve tulip growth parameters.

\section{Materials and Methods}

\section{Plant material and experimental treatments}

The impact of different rates of ethanol and methanol was studied on some traits of tulips (Tulipa 'Rosalie') in a factorial experimental design with two factors of ethanol at four levels $(0,10 \%, 20 \%$, and $30 \%)$ and methanol at four levels $(0,10 \%$, $20 \%$, and $30 \%$ ) with 3 replications (Figure 1).

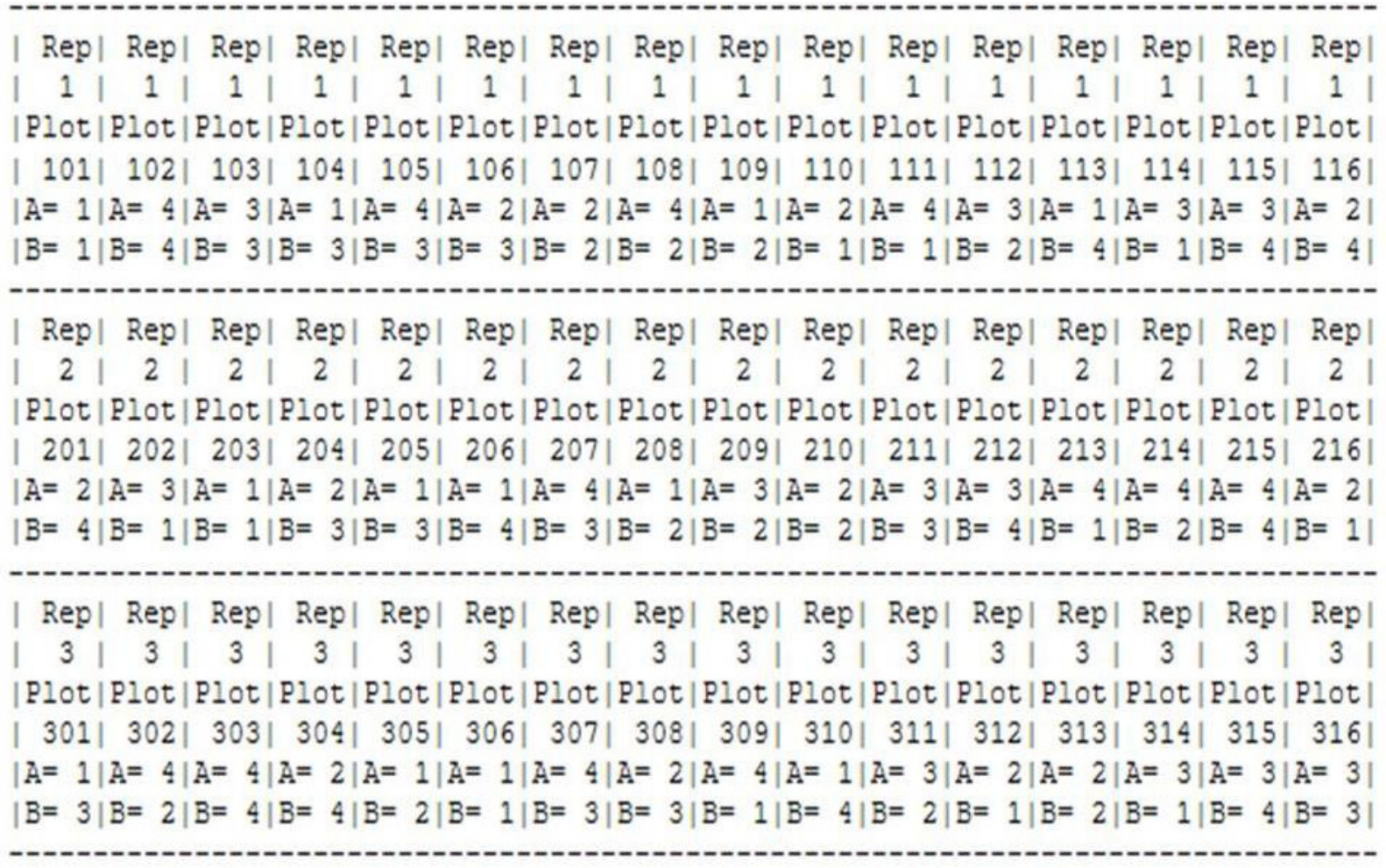

Figure 1. Experimental map: randomized arrangement of plants in the experiment. A: four levels of ethanol $(0,10 \%, 20 \%$, and $30 \%)$ and $\mathrm{B}$ : four levels of methanol $(0,10 \%, 20 \%$, and $30 \%)$. 
Tulipa 'Rosalie' is originated from the Netherlands. The planted leaves of bulbous plants were sprayed with ethanol and methanol applied in percentage by volume $(0,10 \%, 20 \%$, and 30 vol\%). Ethanol (96\%) and methanol (96\%) were supplied by Zagros Petrochemical Company (Bushehr, Iran). The first treatment was applied immediately after the emergence of the first leaf bud on February 26, 2016. The second to fifth foliar applications were applied weekly until March 25, 2016 (flower initiation). Both ethanol and methanol were applied at a rate of $10 \mathrm{~mL} /$ plant on the leaves. The trial was carried out in a greenhouse in the cocopeat (Asia Mines and Minerals Development Company) and garden soil medium. The pots were filled with a mixture of garden soil and cocopeat $(1: 1$ $\mathrm{v} / \mathrm{v})$. There were 2 bulbs in each plot and a total of 96 bulbs were planted. Each plot included two 2 L pots $(17 \times 13 \times$ $\left.12 \mathrm{~cm}^{3}\right)$. Relative humidity and temperature in the plastic greenhouse were $75 \%-85 \%$ and $20-27{ }^{\circ} \mathrm{C}$, respectively. Weed and pest control and fertilization (with NPK) were done when required (two times). Liquid NPK (Plant Feeder 8-8-8) was sprayed on all plants. This study has been tested in a research small scale, so the results in bigger scale might be different.

\section{Measurements}

The recorded traits included leaf number, flowering stalk length, leaf length and width, leaf area, total plant fresh and dry weight, and bulb fresh and dry weight.

Leaf area was estimated by the following equation (Palaniswamy and Gomez, 1974):

$$
\text { Leaf area }=(\text { length } \times \text { width }) \times 0.75
$$

To estimate plant and bulb fresh and dry weights, the harvested plants were weighed. Then, they were re-weighed after oven-drying (Pars Azma Co, model K.J 25, made in Iran) at $105{ }^{\circ} \mathrm{C}$ for 24 -hours. All flowers were harvested at the wilting stage (petals wilting and abscission).

To measure the chlorophyll content of the leaves, different treatments were sampled 7 days after treating. Then, $0.5 \mathrm{~g}$ of the sample was weighed and grounded in a Chinese mortar containing $50 \mathrm{~mL}$ acetone $80 \%(80$ $\mathrm{mL}$ acetone $+20 \mathrm{~mL}$ distilled water). The extract was infiltrated, reached $50 \mathrm{cc}$, and poured into small containers. The absorption maxima of chlorophyll $a$ and chlorophyll $b$ were recorded at 643 and $660 \mathrm{~nm}$ by a JASCO Model V-530 spectrophotometer. Then, the recorded figures (A) were put in the following equation to calculate total chlorophyll and chlorophyll $a$ and $b$ (Mazumdar and Majumder, 2017):

$$
\begin{gathered}
\text { Total chlorophyl } 1(\mathrm{mg} / \mathrm{ml})=7.12\left(\mathrm{~A}_{660}\right)+16.8\left(A_{643}\right) \\
\text { Chlorophyl } 1 \mathrm{a}(\mathrm{mg} / \mathrm{ml})=9.93\left(\mathrm{~A}_{660}\right)-0.777\left(A_{643}\right) \\
\text { Chlorophyl } 1 \mathrm{~b}(\mathrm{mg} / \mathrm{ml})=17.6\left(\mathrm{~A}_{660}\right)-2.81\left(A_{643}\right)
\end{gathered}
$$

To measure anthocyanin, $0.5 \mathrm{~g}$ of each sample (leaf) was weighed and ground in a mortar containing $50 \mathrm{~mL}$ ethanol hydrochloric acid $(85 \%$ ethanol $95 \%+15 \%$ hydrochloric acid). Then, the extract was infiltrated, reached $50 \mathrm{~mL}$, and poured into small containers. The containers were placed in a refrigerator at $4{ }^{\circ} \mathrm{C}$ for 24 -hours. After that, they were kept in darkness for 2-hours. The extracts were read at 535 nm with a JASCO Model V-530 spectrophotometer, and anthocyanin content was estimated by (Mazumdar and Majumder, 2017):

$$
\text { Total absorption of sample }=\frac{\mathrm{e} \times \mathrm{b} \times \mathrm{c}}{\mathrm{d} \times \mathrm{a}} \times 100
$$

where,

$$
\begin{aligned}
& \mathrm{a}=\text { the sample weight }(0.5 \mathrm{~g}), \\
& \mathrm{b}=\text { the volume taken for measurements }(5 \mathrm{cc}) \\
& \mathrm{c}=\text { total volume }(50 \mathrm{cc}) \\
& \mathrm{d}=\text { the fraction taken as sample } 0.1 \\
& \mathrm{e}=\text { the read figure at } 535 \mathrm{~nm}
\end{aligned}
$$

Total anthocyanin of sample $=\frac{\text { total absorption of sample }}{98.2}$

Carotenoid content was measured on samples taken from all treatments. So, $0.5 \mathrm{~g}$ of the sample was ground in a Chinese mortar containing $50 \mathrm{~mL}$ acetone $80 \%(80$ $\mathrm{mL}$ acetone $+20 \mathrm{~mL}$ distilled water). Then, the extract was infiltrated, adjusted to $50 \mathrm{cc}$, and placed in small containers. They were read at 645,663 , and $660 \mathrm{~nm}$. Then, the figures (A) were put in the following equation to determine the carotenoid content of the treatments (Mazumdar and Majumder, 2017).

$$
\text { Carotenoid content }=4.69\left(\mathrm{~A}_{660}\right)-0.268\left(\mathrm{~A}_{645}\right)+8.02\left(\mathrm{~A}_{663}\right)
$$

To measure stem and leaf Brix index, a part of the stem and leaf tissue was cut. The stem and leaf tissue was placed in a simple squeezer and its sap was poured on the glass plate of a refractometer, Brix figure was estimated, and finally, the total soluble solids (TSS) content was specified according to the Brix table.

Data were analyzed by MSTATC statistical package for the experiment arranged in a Randomized Complete Block Design (with 48 treatments or samples). The data tested for independent and normal distribution before ANOVA analysis. Two-way ANOVA was used to assess the effect of each type of alcohol and the interactions. Means were compared by the LSD test after ANOVA analysis.

\section{Results and Discussion}

According to the analysis of variance (Table 1), the effect of experimental factors and the interactions between treatments were significant for the anthocyanin content of tulip flowers at the $1 \%$ level. 
Table 1. Analysis of variance for the effect of ethanol and methanol on the physiological and morphological traits

\begin{tabular}{|c|c|c|c|c|c|c|c|c|c|c|c|c|c|}
\hline \multirow[b]{2}{*}{$\begin{array}{l}\text { Source of } \\
\text { Variables }\end{array}$} & \multicolumn{13}{|c|}{ Means of squares } \\
\hline & $\begin{array}{l}\text { Antho- } \\
\text { cyanin }\end{array}$ & $\begin{array}{l}\text { Carote- } \\
\text { noid }\end{array}$ & $\begin{array}{c}\text { Chloro- } \\
\text { phyll } \\
a\end{array}$ & $\begin{array}{c}\text { Total } \\
\text { chloro- } \\
\text { phyll }\end{array}$ & $\begin{array}{l}\text { Leaf } \\
\text { Brix }\end{array}$ & $\begin{array}{l}\text { Stem } \\
\text { Brix }\end{array}$ & $\begin{array}{c}\text { Floral } \\
\text { stalk } \\
\text { length }\end{array}$ & $\begin{array}{c}\text { Leaf } \\
\text { width }\end{array}$ & $\begin{array}{c}\text { Leaf } \\
\text { length }\end{array}$ & $\begin{array}{l}\text { Leaf } \\
\text { area }\end{array}$ & $\begin{array}{c}\text { Total } \\
\text { fresh } \\
\text { weight }\end{array}$ & $\begin{array}{c}\text { Bulb fresh } \\
\text { weight }\end{array}$ & $\begin{array}{c}\text { Bulb dry } \\
\text { weight }\end{array}$ \\
\hline Replication & $1.52 \mathrm{~ns}$ & $0.64 \mathrm{~ns}$ & $3.32 *$ & $1.89 \mathrm{~ns}$ & $3.30 \mathrm{~ns}$ & $0.54 \mathrm{~ns}$ & $227.70^{*}$ & $1.90 \mathrm{~ns}$ & $4.75 \mathrm{~ns}$ & $1161.57 \mathrm{~ns}$ & $114.87 * *$ & $5.01 \mathrm{~ns}$ & $1.78 \mathrm{~ns}$ \\
\hline Ethanol & $10.45^{* *}$ & $0.51 \mathrm{~ns}$ & $0.71 \mathrm{~ns}$ & $1.57 \mathrm{~ns}$ & $2.46 \mathrm{~ns}$ & $0.33 \mathrm{~ns}$ & $309.57 * *$ & $3.25 \mathrm{~ns}$ & $16.74 *$ & $4867.73 *$ & $48.47 \mathrm{~ns}$ & $40.93^{* *}$ & $2.50 \mathrm{~ns}$ \\
\hline Methanol & $4.97 * *$ & $0.83 \mathrm{~ns}$ & $1.52 \mathrm{~ns}$ & $1.40 \mathrm{~ns}$ & $7.65^{* *}$ & $0.94 \mathrm{~ns}$ & $257.99 *$ & $0.97 \mathrm{~ns}$ & $9.08 \mathrm{~ns}$ & $521.64 \mathrm{~ns}$ & $26.24 \mathrm{~ns}$ & $19.99 \mathrm{~ns}$ & $1.81 \mathrm{~ns}$ \\
\hline $\begin{array}{l}\text { Ethanol } \times \\
\text { methanol }\end{array}$ & $3.11 * *$ & $3.91 * *$ & $1.84 *$ & $6.66^{*}$ & $3.26^{*}$ & $1.62 *$ & $414.39 * *$ & $2.44 \mathrm{~ns}$ & $10.85 \mathrm{~ns}$ & $3781.48 * *$ & $42.18^{*}$ & $14.40 \mathrm{~ns}$ & $1.86 \mathrm{~ns}$ \\
\hline Error & 0.82 & 0.40 & 0.78 & 2.71 & 1.17 & 0.66 & 58.83 & 1.19 & 5.71 & 1093.39 & 17.49 & 6.96 & 0.95 \\
\hline CV (\%) & 34.17 & 13.18 & 53.30 & 31.15 & 12.05 & 9.83 & 39.02 & 8.24 & 9.39 & 12.92 & 10.18 & 11.27 & 14.48 \\
\hline
\end{tabular}

$\mathrm{ns}, *$ and $* *$ show insignificant and significant differences at 1 and $5 \%$ level, respectively according to ANOVA. Ninety-six plants (samples) were used for the analysis.

The highest anthocyanin content was related to the treatment of $30 \%$ ethanol and the lowest to $20 \%$ ethanol (Table 2).

Means comparison to investigate the effect of methanol on anthocyanin content (Table 3) revealed that 30\% methanol had the highest anthocyanin content, and $0 \%$ methanol (control) had the lowest one.

According to results for ethanol $\times$ methanol interaction, the highest anthocyanin content was produced under $30 \%$ ethanol $\times 30 \%$ methanol (Table 4 ).

Table 2. Means comparison for the effect of ethanol on the physiological and morphological traits $(n=4)$

\begin{tabular}{|c|c|c|c|c|c|}
\hline Treatment & $\begin{array}{c}\text { Anthocyanin } \\
\left(\mathbf{m g} \mathbf{1 0 0} \mathbf{g}^{-1} \mathbf{D M}\right)\end{array}$ & $\begin{array}{c}\text { Leaf length } \\
\mathbf{( \mathbf { c m } )}\end{array}$ & $\begin{array}{c}\text { Leaf area } \\
\mathbf{( \mathbf { c m } ^ { 2 } )}\end{array}$ & $\begin{array}{c}\text { Flowering stalk } \\
\text { length } \mathbf{( c m )}\end{array}$ & $\begin{array}{c}\text { Bulb fresh weight } \\
\mathbf{( g )}\end{array}$ \\
\hline $0 \%$ ethanol & $2.79 \mathrm{~b}$ & $23.75 \mathrm{~b}$ & $226.8 \mathrm{~b}$ & $18.61 \mathrm{~b}$ & $21.88 \mathrm{~b}$ \\
\hline $10 \%$ ethanol & $1.97 \mathrm{c}$ & $25.67 \mathrm{ab}$ & $266.8 \mathrm{a}$ & $26.98 \mathrm{a}$ & $22.03 \mathrm{~b}$ \\
\hline $20 \%$ ethanol & $1.92 \mathrm{c}$ & $26.50 \mathrm{a}$ & $271.5 \mathrm{a}$ & $15.27 \mathrm{~b}$ & $23.89 \mathrm{ab}$ \\
\hline $30 \%$ ethanol & $3.92 \mathrm{a}$ & $25.83 \mathrm{a}$ & $258.6 \mathrm{a}$ & $17.77 \mathrm{~b}$ & $25.81 \mathrm{a}$ \\
\hline SD & \pm 0.81 & \pm 1.022 & \pm 17.43 & \pm 4.40 & \pm 1.59 \\
\hline
\end{tabular}

Similar letter(s) in each column show insignificant differences at the 1 and $5 \%$ probability levels according to the LSD test. Twenty-four samples were used per treatment.

Table 3. Means comparison for the effect of methanol on the physiological and morphological traits $(n=4)$

\begin{tabular}{|c|c|c|c|c|}
\hline Treatment & $\begin{array}{c}\text { Anthocyanin } \\
\left(\mathrm{mg} 100 \mathrm{~g}^{-1} \mathrm{DM}\right)\end{array}$ & $\begin{array}{l}\text { Leaf Brix } \\
(\%)\end{array}$ & $\begin{array}{l}\text { Flowering stalk length } \\
\text { (cm) }\end{array}$ & $\begin{array}{c}\text { Bulb fresh weight } \\
\text { (g) }\end{array}$ \\
\hline $0 \%$ methanol & $1.92 \mathrm{c}$ & $8.71 \mathrm{~b}$ & $24.67 \mathrm{a}$ & $22.07 \mathrm{~b}$ \\
\hline $10 \%$ methanol & $2.44 \mathrm{bc}$ & $8.57 \mathrm{~b}$ & $16.48 \mathrm{bc}$ & $23.65 \mathrm{ab}$ \\
\hline $20 \%$ methanol & $2.78 \mathrm{ab}$ & $8.43 \mathrm{~b}$ & $15.02 \mathrm{c}$ & $22.80 \mathrm{~b}$ \\
\hline $30 \%$ methanol & $3.45 \mathrm{a}$ & $10.15 \mathrm{a}$ & $22.46 \mathrm{ab}$ & $25.08 \mathrm{a}$ \\
\hline SD & \pm 0.555 & \pm 0.69 & \pm 4.018 & \pm 1.119 \\
\hline
\end{tabular}

Similar letter(s) in each column show insignificant differences at the 1 and $5 \%$ probability levels according to the LSD test. Twenty-four samples were used per treatment. 
Table 4. Means comparison for ethanol $\times$ methanol interaction for the physiological and morphological traits $(n=16)$

\begin{tabular}{|c|c|c|c|c|c|c|c|c|c|c|}
\hline Treatment & $\begin{array}{l}\text { Anthocy- } \\
\text { anin } \\
\text { (mg 100 } \\
\left.\mathrm{g}^{-1} \mathrm{DW}\right)\end{array}$ & $\begin{array}{l}\text { Carot- } \\
\text { enoid } \\
\left(\mathrm{g} \mathrm{\textrm {l } ^ { - 1 }}\right)\end{array}$ & $\begin{array}{l}\text { Chloro- } \\
\text { phyll } a \\
\left(\mathrm{mg} \mathrm{ml}^{-1}\right)\end{array}$ & $\begin{array}{c}\text { Total } \\
\text { chloro- } \\
\text { phyll } \\
\left(\mathbf{m g ~ m l}^{-1}\right)\end{array}$ & $\begin{array}{c}\text { Leaf Brix } \\
(\%)\end{array}$ & $\begin{array}{c}\text { Stem Brix } \\
(\%)\end{array}$ & $\begin{array}{c}\text { Floral } \\
\text { stalk } \\
\text { length } \\
(\mathrm{cm})\end{array}$ & $\begin{array}{c}\text { Leaf } \\
\text { length } \\
\text { (cm) }\end{array}$ & $\begin{array}{c}\text { Leaf area } \\
\left(\mathrm{cm}^{2}\right)\end{array}$ & $\begin{array}{c}\text { Total } \\
\text { fresh } \\
\text { weight } \\
\text { (g) }\end{array}$ \\
\hline$a_{1} b_{1}$ & $1.67 \mathrm{de}$ & $2.08 \mathrm{~g}$ & $1.45 \mathrm{e}$ & $3.14 \mathrm{~d}$ & $8.27 \mathrm{~d}$ & 8.43 a-e & $9.77 \mathrm{f}$ & $21.00 \mathrm{~d}$ & $192.3 \mathrm{e}$ & $31.05 \mathrm{~d}$ \\
\hline$a_{1} b_{2}$ & $3.14 \mathrm{bcd}$ & $2.76 \mathrm{fg}$ & $2.71 \mathrm{a}-\mathrm{e}$ & $3.95 \mathrm{bcd}$ & $8.77 \mathrm{~cd}$ & $8.75 \mathrm{a}-\mathrm{d}$ & $17.33 \mathrm{c}-\mathrm{f}$ & $25.00 \mathrm{bc}$ & $230.8 \mathrm{de}$ & $45.06 \mathrm{a}$ \\
\hline$a_{1} b_{3}$ & $3.08 \mathrm{bcd}$ & $2.78 \mathrm{fg}$ & $2.92 \mathrm{a}-\mathrm{e}$ & 5.32 a..d & $8.40 \mathrm{~d}$ & $8.45 a-e$ & $17.33 \mathrm{c}-\mathrm{f}$ & $24.33 \mathrm{bcd}$ & $231.0 \mathrm{de}$ & $37.50 \mathrm{~cd}$ \\
\hline$a_{1} b_{4}$ & $3.26 \mathrm{bc}$ & $5.37 \mathrm{a}$ & $4.14 \mathrm{ab}$ & $6.56 \mathrm{ab}$ & $11.00 \mathrm{ab}$ & $8.25 \mathrm{a}-\mathrm{e}$ & $30.00 \mathrm{abc}$ & $24.67 \mathrm{bcd}$ & $253.0 \mathrm{bcd}$ & $41.64 \mathrm{abc}$ \\
\hline$a_{2} b_{1}$ & $0.55 \mathrm{e}$ & $2.67 \mathrm{fg}$ & $2.93 \mathrm{a}-\mathrm{d}$ & 5.74 a..d & $8.40 \mathrm{~d}$ & $8.93 \mathrm{abc}$ & $23.90 \mathrm{~b}-\mathrm{e}$ & $27.33 \mathrm{ab}$ & $288.3 \mathrm{abc}$ & $41.07 \mathrm{abc}$ \\
\hline$a_{2} b_{2}$ & $0.90 \mathrm{e}$ & $5.05 \mathrm{ab}$ & $3.32 \mathrm{a}-\mathrm{d}$ & 5.10 a..d & $7.90 \mathrm{~d}$ & $7.50 \mathrm{de}$ & $32.33 \mathrm{ab}$ & $27.33 \mathrm{ab}$ & $288.8 \mathrm{abc}$ & $38.81 \mathrm{abc}$ \\
\hline$a_{2} b_{3}$ & $3.84 \mathrm{abc}$ & $2.91 \mathrm{efg}$ & $2.61 \mathrm{cde}$ & $4.24 \mathrm{bcd}$ & $8.00 \mathrm{~d}$ & 7.80 b..e & $11.67 \mathrm{ef}$ & $23.33 \mathrm{~cd}$ & 245.0 b..e & $41.93 \mathrm{abc}$ \\
\hline$a_{2} b_{4}$ & $2.59 \mathrm{bcd}$ & $3.89 \mathrm{cde}$ & $3.35 \mathrm{a}-\mathrm{d}$ & $6.53 \mathrm{ab}$ & $11.67 \mathrm{a}$ & $9.25 \mathrm{a}$ & $40.00 \mathrm{a}$ & $24.67 \mathrm{bcd}$ & 245.0 b..e & $38.50 \mathrm{abc}$ \\
\hline$a_{3} b_{1}$ & $2.46 \mathrm{~cd}$ & 3.95 c..f & 2.30 acde & $6.04 \mathrm{abc}$ & $7.77 \mathrm{~d}$ & $7.50 \mathrm{de}$ & $25.33 \mathrm{bcd}$ & $26.33 \mathrm{abc}$ & 276.5 a..d & $44.57 \mathrm{ab}$ \\
\hline$a_{3} b_{2}$ & $1.69 \mathrm{de}$ & $2.95 \mathrm{efg}$ & $3.55 \mathrm{a}-\mathrm{d}$ & 5.36 a..d & $9.07 \mathrm{~cd}$ & $8.63 \mathrm{a}-\mathrm{e}$ & $9.60 \mathrm{f}$ & $25.33 \mathrm{bc}$ & 241.3 cde & $43.89 a b c$ \\
\hline$a_{3} b_{3}$ & $0.49 \mathrm{e}$ & 3.59 c..f & $2.84 \mathrm{a}-\mathrm{e}$ & $4.11 \mathrm{bcd}$ & $7.93 \mathrm{~d}$ & $7.60 \mathrm{cde}$ & $17.67 \mathrm{c}-\mathrm{f}$ & $24.33 \mathrm{bcd}$ & 237.2 cde & $37.76 \mathrm{bcd}$ \\
\hline$a_{3} b_{4}$ & $3.05 \mathrm{bcd}$ & $3.23 \mathrm{def}$ & $2.69 \mathrm{~b}-\mathrm{e}$ & $6.32 \mathrm{ab}$ & $8.60 \mathrm{~cd}$ & $9.10 \mathrm{ab}$ & $8.50 \mathrm{f}$ & $30.00 \mathrm{a}$ & $330.9 \mathrm{ab}$ & $42.48 \mathrm{abc}$ \\
\hline$a_{4} b_{1}$ & $2.99 \mathrm{bcd}$ & $4.14 \mathrm{bcd}$ & $3.32 \mathrm{a}-\mathrm{d}$ & 4.98 a..d & $10.40 \mathrm{abc}$ & $7.37 \mathrm{e}$ & $39.67 \mathrm{a}$ & $25.00 \mathrm{bc}$ & $249.5 \mathrm{bcd}$ & $43.34 a b c$ \\
\hline$a_{4} b_{2}$ & $4.05 \mathrm{ab}$ & $3.33 \mathrm{def}$ & $3.70 \mathrm{abc}$ & $7.27 \mathrm{a}$ & $8.53 \mathrm{~d}$ & 7.77 b-e & $6.67 \mathrm{f}$ & $26.33 \mathrm{abc}$ & $251.5 \mathrm{bcd}$ & $43.07 a b c$ \\
\hline$a_{4} b_{3}$ & $3.71 \mathrm{abc}$ & $4.60 \mathrm{abc}$ & $4.17 \mathrm{a}$ & $6.465 \mathrm{ab}$ & $9.40 \mathrm{bcd}$ & $9.10 \mathrm{ab}$ & $13.43 \mathrm{def}$ & $26.00 \mathrm{bc}$ & $299.5 \mathrm{ab}$ & $41.47 \mathrm{abc}$ \\
\hline$a_{4} b_{4}$ & $4.91 \mathrm{a}$ & $2.55 \mathrm{fg}$ & $2.16 \mathrm{de}$ & $3.39 \mathrm{~cd}$ & $9.33 \mathrm{bcd}$ & $8.17 \mathrm{a}-\mathrm{e}$ & $11.33 \mathrm{ef}$ & $26.00 \mathrm{bc}$ & $234.0 \mathrm{cde}$ & $45.17 \mathrm{a}$ \\
\hline SD & \pm 1.24 & \pm 0.912 & \pm 0.696 & \pm 1.197 & \pm 1.12 & \pm 0.62 & \pm 10.63 & \pm 1.91 & \pm 32.33 & \pm 3.54 \\
\hline
\end{tabular}

$\mathrm{a}_{1}: 0 \%$ ethanol; $\mathrm{a}_{2}: 10 \%$ ethanol; $\mathrm{a}_{3}: 20 \%$ ethanol; $\mathrm{a}_{4}: 30 \%$ ethanol; $\mathrm{b}_{1}: 0 \%$ methanol; $\mathrm{b}_{2}: 10 \%$ methanol; $\mathrm{b}_{3}: 20 \%$ methanol; $\mathrm{b}_{4}: 30 \%$ methanol

Similar letter(s) in each column show insignificant differences at the 1 and $5 \%$ probability levels according to the LSD test. Six samples were used per combined treatment.

Amini et al. (2014) reported the different concentrations of ethanol $(4 \%, 6 \%$, and $12 \%)$ and methanol $(6 \%)$ could increase anthocyanin content of cut carnation (Dianthus caryophyllus cv. 'Sensi') petals. Anthocyanins are the largest and most important pigments of vacuolar in the plant species (Fernández-López et al., 2020). The flavonoid pigments are responsible for the red, blue, and purple colors of most fruits, vegetables, and flowers. These pigments, in particular, and all phenolic compounds, in general, protect plants against ultraviolet radiation and insects (Buchert et al., 2005). Natural pigments (including carotenoids, anthocyanins, and betacyanins), apart from color, provide extra properties and are, therefore, considered to be bioactive constituents (Khoo et al., 2017). Humans have always incorporated the natural pigments of fruits, vegetables, and ornamental plants in their life. Currently, natural pigments are used widely as additives or supplements in the food industry. Typical red carotenoid-pigmented fruits are tomato (Solanum lycopersicum), watermelon (Citrullus lanatus) and red pepper (Capsicum annuum) (Fernández-López et al., 2020). El Kereamy et al. (2002) reported that ethanol treatment triggers triggered gene expression leading to anthocyanin accumulation during grape ripening. The effect of ethanol spraying on anthocyanin accumulation in ripening berries seems to be due to its stimulatory effect on UFGT gene transcription.

According to Table 1 , ethanol $\times$ methanol interaction was significant for the carotenoid content of tulip flowers $(p<0.01)$, but the simple effects of ethanol and methanol were not significant for this trait. Accordingly, $0 \%$ ethanol $\times 30 \%$ methanol was related to the highest carotenoid content and $0 \%$ ethanol $\times 0 \%$ methanol was related to the lowest one. Kiaseh and Yadegari (2016) stated that ethyl alcohol avoided the formation of anthocyanin in the petals of Alstroemeria hybrida flowers and provided the chance to preserve the natural color of flowers in the vase life. These results about anthocyanin are contrary to our results. Samadimatin and Hani (2017) found that the simple effect of ethanol on carotenoid content was not significant. Moreover, the interaction of humic acid and ethanol was significant on carotenoid content and $15 \%$ ethanol caused to increase in carotenoid content of Dracocephalum moldavica compared to control.

The analysis of variance revealed the significant impact of ethanol $\times$ methanol interaction on chlorophyll $a$ of tulip flower $(p<0.05)$ (Table 1$)$, but different rates of ethanol and methanol did not alone change this trait significantly. According to Table 4, 30\% ethanol $\times 20 \%$ methanol resulted in the highest chlorophyll $a$ content, and $0 \%$ ethanol $\times 0 \%$ methanol resulted in the lowest one. As revealed by the analysis of variance (Table 1), the simple effects of ethanol and methanol were insignificant on total chlorophyll content, but ethanol $\times$ methanol interaction was significant for this trait $(p<0.05)$. The highest total chlorophyll was observed in the plants treated with $30 \%$ ethanol $\times 10 \%$ methanol and the lowest one was obtained when no alcohol was applied (Figure 2). 
"Chlorophyll a $\quad$ Total chlorophyll

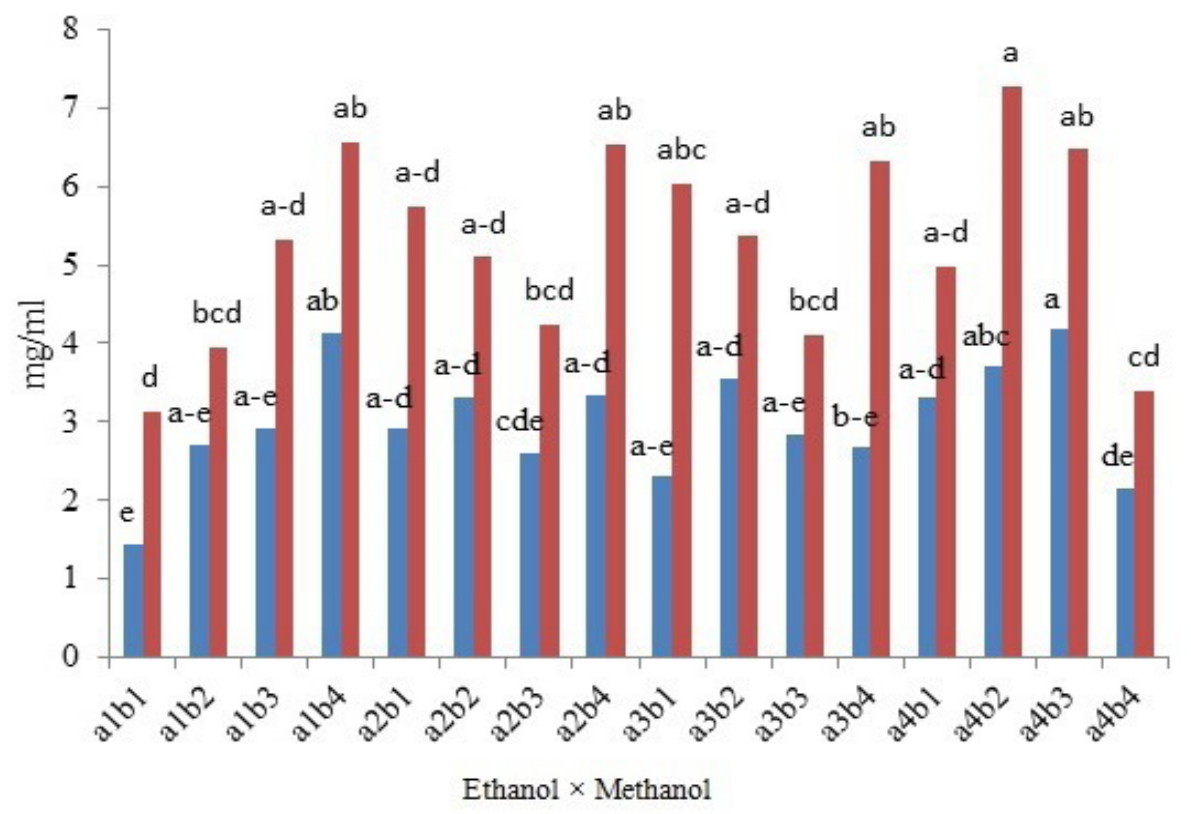

Figure 2. The comparison of means for ethanol $\times$ methanol interaction on chlorophyll $a$ and total chlorophyll. $a_{1}: 0 \%$ ethanol; $a_{2}: 10 \%$ ethanol; $a_{3}: 20 \%$ ethanol; $a_{4}: 30 \%$ ethanol; $b_{1}: 0 \%$ methanol; $b_{2}: 10 \%$ methanol; $b_{3}: 20 \%$ methanol; $b_{4}: 30 \%$ methanol

Ethanol was converted into formaldehyde after penetrating plant tissue (lettuce) and finally oxidized to $\mathrm{CO}_{2}$ (Morales and Santos, 1997). The interaction of humic acid and ethanol improved morphological characteristics, photosynthetic pigments, and yield of essential oil of Dracocephalum moldavica (Samadimatin and Hani, 2017). Mehrabani (2019) found that foliar application of methanol improved the chlorophyll content in leaves and the results indicated that the foliar application of methanol ameliorated the negative effects of salinity in Pelargonium graveolens by improving of photosynthesis pigments. Methanol spraying positively affected the chlorophyll content in Calendula officinalis (Vojodi et al., 2017).

The analysis of variance for leaf Brix index (Table 1) showed the significant effect of methanol $(p<0.01)$ and ethanol $\times$ methanol interaction $(p<0.05)$. The highest leaf Brix index was observed in the plants treated with $30 \%$ methanol (Table 3). Methanol can act as an alternative source of carbon, causing a considerable increase in their $\mathrm{CO}_{2}$ fixation, growth, and yield, mainly due to inhibiting their photorespiration (Tavassoli and Galavi, 2011). The positive effect of methanol in plants is due to its fast uptake and quick metabolize to $\mathrm{CO}_{2}$ in plant tissues (Tavassoli and Galavi, 2011). As well, the highest and lowest leaf Brix was observed in $10 \%$ ethanol $\times 30 \%$ methanol and $20 \%$ ethanol $\times 0 \%$ methanol, respectively (Table 4$)$. The treatment with $10 \%$ ethanol $\times 30 \%$ methanol enhanced leaf and stem Brix. The analysis of variance (Table 1 ) revealed that ethanol $\times$ methanol interaction was significant for stem Brix index $(p<0.05)$, but the simple effect of the treatments was not significant. The highest stem Brix was observed in 10\% ethanol $\times 30 \%$ methanol and the lowest in $30 \%$ ethanol $\times$ $0 \%$ methanol (Table 4). Methanol boosts sugar content and cell turgor in leaves, helping the growth and development of leaves and increasing chlorophyll and carotenoids (Zbiec et al., 2003). The present study also showed that methanol application resulted in a higher Brix (sugar) index. The application of methanol increased TSS and anthocyanin content in grapevine berry skins (Ramadan and Omran, 2005).

The analysis of variance (Table 1) indicated that the simple effect of ethanol, methanol, and their interaction were significant on floral stalk length (at least $p<0.05$ ). According to the means comparison (Table 2), 10\% ethanol resulted in the longest stalk of $26.98 \mathrm{~cm}$. Data for the influence of methanol on floral stalk length (Table 3) showed that the longest stalk of $24.67 \mathrm{~cm}$ was obtained from $0 \%$ methanol. As the means comparison for interactions (Table 4) showed, the longest flowering stalk of $40 \mathrm{~cm}$ was obtained from $10 \%$ ethanol $\times 30 \%$ methanol and the shortest one from $30 \%$ ethanol $\times 10 \%$ methanol. A study on cotton (Gossypium hirsutum L.) showed that the application of $30 \%$ methanol hydro-alcohol increased plant height over control (Makhdum et al., 2002). In the present study, the simple effect of methanol on stalk length was negative, which is contrary to Makhdum et al.(2002) results. In a study on Echinacea purpurea L., plant height was increased in the treatment of 30\% methanol hydroalcohol, but the tallest plants were observed in the foliar application of $40 \%$ methanol hydro-alcohol, and higher methanol rate (i.e. 50\%) resulted in the loss of plant height despite producing more flowers (Khosravi et al., 2016b). In another study on Melissa officinalis L., plant height was maximized by the foliar application of $30 \%$ methanol, but the application of $40 \%$ methanol decreased it (Khosravi et al., 2016a). 
The analysis of variance (Table 1) indicated that leaf length was significantly influenced by ethanol $(p<0.05)$, but it was not significantly affected by ethanol $\times$ methanol interaction. Based on the means comparison (Table 2), the treatments of $30 \%$ and $20 \%$ ethanol produced the highest leaf length. There was no statistically significant difference between the effects of $20 \%$ and $30 \%$ ethanol on the leaf length. Although the analysis of variance showed that ethanol $\times$ methanol interaction was insignificant for this trait, $20 \%$ ethanol $\times 30 \%$ methanol was related to the highest leaf length of $30 \mathrm{~cm}$ and $0 \%$ ethanol $\times 0 \%$ methanol was related to the lowest leaf length of $21 \mathrm{~cm}$. Khosravi et al. (2016b) observed the highest leaf length in the foliar application of $30 \%$ and $40 \%$ methanol. In an assessment of the impact of methanol and ethanol on P. psyllium by Larzghadiri et al. (2013), the highest leaf length was obtained from the treatment of $30 \%$ methanol. The application time, method, and leaf morphology play an important role in plants' responses to methanol and ethanol application (Mehrabani, 2019; Ramberg et al., 2002).

According to the analysis of variance, leaf area was significantly affected by ethanol $(p<0.05)$ and ethanol $\times$ methanol interaction $(p<0.01)$, whereas methanol did not change it significantly. The means comparison (Table 2) revealed insignificant differences among ethanol rates on leaf area, but the highest leaf area of $271.5 \mathrm{~cm}^{2}$ was related to the treatment of $20 \%$ ethanol. Also, the means comparison (Table 4) revealed that the highest leaf area of $330 \mathrm{~cm}^{2}$ was obtained from the treatment of $20 \%$ ethanol $\times 30 \%$ methanol. Tochaei et al. (2018) reported that the foliar treatment of groundnut shoot with methanol and ascorbic acid can increase grain yield and yield components. In a study on the effect of methanol spraying on soybeans, Mirakhoondi et al. (2010) concluded that the foliar application of methanol improved leaf area and total biomass. The plants treated with $40 \%$ methanol hydroalcohol exhibited a higher leaf area, and an increase in methanol rate up to $50 \%$ resulted in the loss of leaf area (Khosravi et al., 2016b). In Echinacea purpurea L., the highest leaf area was related to the treatment with $30 \%$ methanol and it was decreased at methanol rates of $40 \%$ and $50 \%$. Different responses of the leaves of these two plants to alcohol treatments with similar concentrations can be ascribed to the different leaf structures and different metabolisms induced by genetic properties (Khosravi et al., 2016b).

Ethanol $\times$ methanol interaction was significant for plant total fresh weight $(p<0.05)$, but ethanol and methanol could not alone change total fresh weight significantly. According to Table 4, the highest plant fresh weight of $45.17 \mathrm{~g}$ was related to the treatment of $30 \%$ ethanol $\times$ $30 \%$ methanol and the lowest fresh weight of $31.05 \mathrm{~g}$ was related to the treatment of $0 \%$ ethanol $\times 0 \%$ methanol. According to Samadimatin and Hani (2017), 10\% ethanol treatment increased the biological yield of aromatic plant Dracocephalum. Both alcohol types, i.e., ethanol and methanol (20\%), increased leaf and stem fresh and dry weights of tomato plants. Methanol leads to a greater increase in stem length and stem weight than ethanol (Rowe et al., 1994).

The analysis of variance (Table 1) indicated that among studied factors and their interactions, the simple effect of ethanol was significant on tulip bulb fresh weight $(p<0.01)$, but the simple effect of methanol and ethanol $\times$ methanol interaction were not significant. It was found that $30 \%$ ethanol was related to the highest bulb fresh weight of $25.81 \mathrm{~g}$ (Table 2). Despite the insignificant influence of methanol and ethanol $\times$ methanol on bulb fresh weight, the highest bulb fresh weights of 25.08 and $28.29 \mathrm{~g}$ were obtained from $30 \%$ ethanol and $30 \%$ ethanol $\times 30 \%$ methanol, respectively. Some reports on the positive effect of the foliar application of methanol on plant growth and yields show that methanol improves biomass in plants suffering from water deficit but results in biomass loss in those possessing adequate water (Valizadeh-Kamran et al., 2019; Nourafcan and Kalantari, 2017; Ramberg et al., 2002; Zbiec et al., 2003). Methanol had a positive effect on morphological traits of peppermint including leaf number and leaf size. Also, ethanol increased essential oil contents, and shoot fresh and dry weight (Nourafcan and Kalantari, 2017). Low concentrations of exogenous methanol can improve the biomass of some microalgal species. In addition, methanol increases growth, photosynthesis. and respiration of Chlamydomonas reinhardtii, which is a unicellular green alga (Stepanov et al., 2020).

\section{Conclusions}

The present study revealed that methanol and ethanol had favorable impacts on physiological and morphological traits of tulips and that $30 \%$ methanol, both by itself and in interactions, had the strongest effect on the estimated traits. Therefore, it can be proposed as the best concentration. Since methanol and ethanol can improve important traits of tulips, such as anthocyanin, TSS, and bulb fresh weight, it can be concluded that they can be used as plant growth regulators.

\section{Author Contribution}

SR: performed the experiments. SS: conceived the study, planned the experiments and analyzed the data, manuscript write and review.

\section{References}

AMINI, S.; ARAB, M.; RAHEMI, M.; RAHIMI, A. Effect of ethanol and methanol on some quantity and quality parameters of cut carnation (Dianthus caryophyllus cv. 'Sensi') flower. Journal of Horticulture Science, v.28, n.2, p.218-227, 2014. https://doi.org/10.22067/jhorts4. v0i0.39401

BENSON, A.A.; NONOMURA A.M. The path of carbon in photosynthesis: Methanol inhibition of glycolic acid accumulation. Photosynthesis Research, v.34, p.196, 1992. 
BUCHERT, J.; KOPONEN, J.M.; SUUTARINEN, M.; MUSTARANTA, A.; LILLE, M.; TÖRRÖNEN, R.; POUTANEN, K. Effect of enzyme-aided pressing on anthocyanin yield and profiles in bilberry and blackcurrant juices. Journal of the Science of Food and Agriculture, v.85, n.15, p.2548-2556, 2005. https://doi.org/10.1002/ jsfa. 2284

EL KEREAMY, A.; CHERVIN, C.; SOUQUET, J.M.; MOUTOUNET, M.; MONJE, M.C.; NEPVEU, F.; MONDIES, H.; ROUSTAN, J.P. Ethanol triggers grape gene expression leading to anthocyanin accumulation during berry ripening. Plant Science, v.163, n.3, p.449454, 2002. https://doi.org/10.1016/s0168-9452(02)001425

FERNÁNDEZ-LÓPEZ, J.A.; FERNÁNDEZ-LLEDÓ, V.; ANGOSTO, J.M. New insights into red plant pigments: more than just natural colorants. RSC Advances, v.10, p.24669-24682, 2020. https://doi.org/10.1039/ D0RA03514A

KHOO, H.E.; AZLAN, A.; TANG, S. T.; LIM, S.M. Anthocyanidins and anthocyanins: colored pigments as food, pharmaceutical ingredients, and the potential health benefits. Food and Nutrition Research, v.61, n.1, 1361779, 2017. https://doi.org/10.1080/16546628.2017.13 61779

KHOSRAVI, E.; MEHRAFARIN, A.; NAGHDIBADI, H.; TAMJIDI, M.; KHOSRAVI, M.T. Yield characteristics of Melissa officinalis L. in response to the foliar application of methanol and ethanol solutions. Planta Medica, v.82, n.5, p.36, 2016a. https://doi.org/10.1055/s-0036-1578738

KHOSRAVI, M.; MEHRAFARIN, A.; NAGHDIBADI, H.; HAJIAGHAEE, R.; KHOSRAVI, E. Effect of methanol and ethanol application on yield of Echinacea purpurea L. in Karaj region. Planta Medica, v.82, n.5, p.35. 2016 b. https://doi.org/10.1055/s-0036-1578737

KIASEH, D.Y.; YADEGARI, M. The effect of ethanol and cycloheximide on the vase life of cut flowers alstroemeria (Alstroemeria hybrida). Journal of Ornamental Plants, v.6, n.2, p.73-82, 2016.

LARZGHADIRI, M.;MEHRAFARIN,A.; NAGHDIBADI, A.; KALIGHI SIGARUDI, F. Effect of foliar application of different rates of methanol and ethanol on some traits of Plantago psyllium. Proceedings of National Conference on Medicinal Herbs and Sustainable Agriculture. 2013.

MAKHDUM, I.M.; NAWAZ, A.; SHAHAB, M.; AHMAD, F.; ILLAHI, F. Physiological response of cotton to methanol foliar application. Journal of Research (Science), v.13, n.1, p.37-43, 2002.
MAZUMDAR, B.C.; MAJUMDER, K. Methods on Physicochemical Analysis of Fruits. 2nd Edition. Delhi: Daya Publishing House. 2017. 250p.

MIRAKHOONDI, M.; PAKNEJAD, F.; ADRAKANI, M.; MORADI, F.; NAZERI, P.; NASRI, M. Effect of methanol spraying on yield and yield components of soybean (Glycine max L.). Agroecology, v.2, 236-244. 2010.

MORADI, P.; ESFAHANI, R.E. Effect of foliar application methanol on the quality and quantity of Artemisia dracunculus L. Electronic Journal of Biology, v.S1, p.24-29, 2016.

MORALES, J.P.; SANTOS, B.M. Effects of different ethanol concentration on the initial growth of lettuce (Lactuca sativa). Proceeding of the Caribbean Food Crop Society, v.33, 442-447, 1997.

NOURAFCAN, H.; KALANTARI, Z. The effect of methanol and ethanol foliar application on peppermint morpho-physiological traits. Agroecology Journal, v.12, n.4, p.1-9, 2017. https://doi.org/10.22034/aej.2017.527809

PALANISWAMY, K.M.; GOMEZ, K.A. Length width method for estimating leaf areas for rice. Agronomy Journal, v. 66, p.430-433. 1974.

RAMADAN, T.; OMRAN, Y.A.M.M. The effect of foliar application of methanol on productivity and fruit quality of grapevine cv. Flame Seedless. Vitis, v.44, n.1, p.11-16, 2005. https://doi.org/10.5073/vitis.2005.44.11-16

RAMBERG, H.A.; BRADLEY, J.C.; OLSON, J.C.; NISHIO, J.N.; MARKWELL, J.; OSTEMAN, J.C. The role of methanol in promoting plant growth: An update review. Reviews of Plant Biochemistry and Biotechnology, v.1, p.113-126, 2002.

RAMÍREZ, I.; DORTA, F.; ESPINOZA, V; JIMÉNEZ, E.; MERCADO, A.; PEÑA-CORTÉS, H. Effects of foliar and root applications of methanol on the growth of Arabidopsis, tobacco, and tomato plants. Journal of Plant Growth Regulation, v.25, p.30-44, 2006. https://doi.org/10.1007/ s00344-005-0027-9

ROWE, R.N.; FARR, D.J.; RICHARDS, B.A.J. Effects of foliar and root applications of methanol or ethanol on the growth of tomato plants (Lycopersicon esculentum Mill). New Zealand Journal of Crop and Horticultural Science, v.22, n.3, p.335-337, 1994. https://doi.org/10.108 0/01140671.1994.9513842

SAJEDI MOGHADAM, S.; MEHRAFARIN, A.; NAGHDIBADI, H.; PAZOKI, A. Evaluation of phytochemical yield of thyme (Thymus vulgaris L.) under foliar application of hydroalcohols. Journal of Medicinal Plants, v.4, n.44, p.130-141, 2012. 
SAMADIMATIN,A.; HANI, A. Effect of ethanol and humic acid foliar spraying on morphological traits, photosynthetic pigments and quality and quantity of essential oil content of Dracocephalum moldavica L. Iranian Journal of Plant Physiology, v.8, n.1, p.2299-2306, 2017.

STEPANOV,S.S.;ZOLOTAREVA,E.K.;BELYAVSKAYA, N.A. The role of catalase in assimilation of exogenous methanol by Chlamydomonas reinhardtii cells. Journal of Applied Phycology, v.32, p.1053-1062, 2020. https://doi. org/10.1007/s10811-019-01962-y

TAVASSOLI, A.; GALAVI, M. Effect of foliar application of methanol on efficiency, production and yield of plants - a review. Indian Journal of Agricultural Research, v.45, p. $1-10,2011$.

TOCHAEI, M.M.; SEIFZADEH, S.; ZAKERIN, H.R.; VALADABADI, S.A. Investigation the effect of methanol and ascorbic acid foliar application on growth and yield of peanut (Arachis hypogaea L.) under rain fed conditions. Crop Physiology Journal. v.9, n.36, p.65-82, 2018.

VALIZADEH-KAMRAN, R.; MEHRABANI, L.V.; PESSARAKLI, M. Effects of foliar application of methanol on some physiological characteristics of Lavandula stoechas L. under $\mathrm{NaCl}$ salinity conditions, Journal of Plant Nutrition, v.42, n.3, p.261-268, 2019. https://doi.or $\mathrm{g} / 10.1080 / 01904167.2018 .1554677$
MEHRABANI, L.V. The effects of methanol and ethanol foliar application under salinity stress on some physiological characteristics of Pelargonium graveolens L. Journal of Plant Physiology and Breeding, v.9, n.1, p.63-73, 2019.

VOJODI, L.; HASSANPOURAGHDAM, M.B.; KAMRAN, R.V.; EBRAHIMZADEH, A. Soil cover effects on yield and some physiological characteristics of marigold (Calendula officinalis L.) under methanol foliar application. Journal of Ornamental Plants, v.7, n.3, p.163-169, 2017.

ZBIEC, I.; KARCZMARCZYK, S.; PODSIADLO, C. Response of some cultivated plants to methanol as compared to supplemental irrigation. Electronic Journal of Polish Agricultural Universities, v.6, n.1, p.1-7 2003.

ZHENG, Y.J.; YANG, Y.Q.; LIANG, S.S.; YI, X.F. Effect of methanol on photosynthesis and chlorophyll fluorescence of flag leaves of winter wheat. Agricultural Sciences in China, v.7, n.4, p.432-437. https://doi.org/10.1016/S16712927(08)60086-3 